\title{
Arkikeskustelun translatoriset käytänteet
}

\author{
Tutkimus kielenvälityksestä suomen- ja \\ brasilianportugalinkielisessä vuorovaikutuksessa
}

\author{
KATARIINA HARJUNPÄ̈̈
}

\section{Väitöksenalkajaisesitelmä Helsingin yliopistossa 29. toukokuuta 2017}

Helsingin Rautatientorilla 500 metrin päässä tästä juhlasalista on turvapaikanhakijoiden leiri, joka on seissyt paikoillaan jo yli sata päivää. Leiri on mielenilmaus kielteisen päätöksen saaneiden turvapaikanhakijoiden pakkopalautuksia vastaan, ja lisäksi se kutsuu meitä paikallisia kohtaamaan eri maista tulleet turvapaikanhakijat kanssaihmisinä.

Leirin 30. päivänä Nour Jamal esitti leirin Facebook-seinällä vapaasti käännettynä seuraavanlaisen kutsun:

(1) Liity seuraamme, olemme ihmisiä ja meillä on ainakin yhteinen kieli jolla voimme puhua, tarjoamme sinulle kupin kuumaa teetä, tule juttelemaan kanssamme niin kerromme, miten meitä on kohdeltu. ${ }^{1}$

Kirjoittaja vetoaa viestissään ensinnäkin ihmisyyteen. Ihmisyys tekee kutsun esittäjästä ja sen vastaanottajista, eli kenestä tahansa meistä, tarpeeksi samanlaisia ymmärtämään toisiamme. Toiseksi kirjoittaja vetoaa siihen, että meillä on yhteinen kieli. Tässä tapauksessa hän tarkoittanee englantia. Vetoomuksen taustalta voi lukea ajatuksen siitä, että vaikka meillä ei olisi muuta yhteistä, pystymme samastumaan toistemme kokemuksiin ja asemaan, jos vain pystymme kommunikoimaan keskenämme.

Kirjoittajan viestissä tiivistyy ajatus perustavanlaatuisesta yksilöiden välisestä yhteydestä ja kokemuksen jakamisen mahdollisuudesta, jota voidaan tieteellisesti nimit-

1. Alkuperäinen viesti: "Please come and join us we are human beings and we have at least a common language we can talk with it and we offer you a hot cup of tea talk to us and know how we been treated?" (Tekstin kieliasua on muokattu.) 
tää intersubjektiivisuudeksi. Kielen avulla on mahdollista saavuttaa yksityiskohtainen, syvällinenkin yhteisymmärrys toisten ihmisten kanssa. Vähintäänkin kielen avulla on mahdollista käsitellä sitä, miten kukin tilanteen ymmärtää ja kokee.

Mutta mitä tapahtuu, kun vuorovaikutuksen osallistujilla ei ole yhteistä kieltä? Miten silloin päästään keskusteluyhteyteen toisten kanssa? Suuri osa esimerkiksi juuri turvapaikanhakijoista ei puhu englantia saati suomea, eikä kovin moni täällä vastaanottavassa päässä puhu heidän kieliään. Ilmiö sinänsä ei ole uusi. Eri kielten puhujat ovat kohdanneet toisiaan ihmiskunnan historiassa aina, muun muassa silloin kun on käyty kauppaa, sodittu, valloitettu muiden kansojen alueita tai menty naimisiin. Yhteisen kielen puutteeseen on oletettavasti silloinkin ollut tarjolla yksi, edelleen käyttökelpoinen ratkaisu: mukaan tulee kolmas, molempien kielten taitaja, joka tulkkaa keskustelua osallistujien välillä.

Tulkkausta - tai suullista kääntämistä, kuten sitä tutkimuksessani kutsun - on todennäköisesti esiintynyt niin kauan kuin on ollut yhteyksiä eri kielten puhujien välillä. Vähitellen tämä kielenvälitystoiminta on muotoutunut omaksi ammattialakseen. On syntynyt erikoisosaamista ja vakiintuneita ammatillisia käytänteitä. Nykyisin esimerkiksi Suomen ulkomaalaislaissa turvataan oikeus tulkkauspalveluihin niille, jotka tarvitsevat tulkkausta viranomaisten kanssa asioidessaan (Ulkomaalaislaki 2004/301 $\$ 203$ ). Turvapaikkapuhutteluissakin on mukana tulkki, joka välittää keskustelua turvapaikanhakijan ja haastattelijan välillä (Maahanmuuttovirasto 2017). Usein tulkkia käytetään siitä huolimatta, että osanottajat voisivat periaatteessa puhua yhteistä vierasta kieltä, vaikkapa englantia. Tulkeilta odotetaan ammatillisten toimintaperiaatteiden noudattamista, kuten puolueettomuutta ja neutraalia puheen välittämistä. Omien näkemysten tai ylimääräisten selitysten esittäminen ei ole sallittua (Asioimistulkin ammattisäännöstö 2013). Tästä huolimatta tulkatun vuorovaikutuksen tutkimukset osoittavat, että tulkki ei ole vain automaattinen puheen toistaja vaan aktiivinen toimija, joka vaikuttaa monin tavoin keskustelun etenemiseen sillä, miten hän tulkkaa (esim. Wadensjö 1998; Bolden 2000; Angermeyer 2015).

Jonkin asian kääntäminen eli esittäminen eri kielellä on aina jossakin määrin uusi tulkinta aiemmin sanotusta. Kääntämistä ei siis voida ajatella ainoastaan jonkin alkuperäisen lähteen toissijaisena versiona, vaan kääntämällä synnytetään ja muokataan ympäröivää todellisuutta hyvin konkreettisinkin tavoin. Esimerkistä käyvät jälleen jo mainitsemani turvapaikkapuhuttelut, joissa turvapaikanhakijat kertovat tulkin välityksellä lähtönsä syistä ja kokemuksistaan lähtömaassa. Viime aikoina on keskustelu siitä, syntyykö turvapaikkahaastattelijoille totuudenmukainen kuva haastateltavien kertomuksista ja osaavatko päätösten tekijät tulkita tuota tietoa oikein päätöksiä tehdessään. On muun muassa määriteltävä, onko hakija kokenut vainoa ja väkivaltaa, joka voisi oikeuttaa turvapaikan saamiseen (esim. niin kutsuttu Lisan tapaus; Reinboth 2017a, 2017b).

Tulkin välityksellä syntyvä kuva hakijan kokemasta todellisuudesta on merkittävässä asemassa siinä, kenelle turvapaikka lopulta myönnetään. Turvapaikkamenettelyn yhtenä haasteena on se, että tarvittavien kielten tulkkeja ei aina ole saatavilla. Lisäksi on käynyt ilmi, että Maahanmuuttovirasto on käyttänyt tulkkeina henkilöitä, jotka eivät osaa tulkattavia kieliä tarpeeksi hyvin tai joilla ei ole riittävää koulutusta (esim. Leinonen 2017; Suomen kääntäjien ja tulkkien liitto 2017). 
Muissakin yhteyksissä on mahdollista, että sopivaa tulkkia ei yksinkertaisesti ole saatavilla. Silloin saatetaan joutua pyytämään apuun kuka tahansa paikalle sattuva, tarvittavia kieliä osaava henkilö. Viime vuosina eri alojen tutkijat ovatkin kiinnostuneet tällaisesta ei-ammattimaisesta kielenvälitystoiminnasta, mistä on myös syntymässä oma tutkimusalansa (Antonini, Cirillo, Rossato \& Torresi 2017; Kolehmainen, Koskinen \& Riionheimo 2015; kootusti Harris 2012). Kimmokkeena kiinnostukselle ovat olleet jossakin määrin ristiriitaiset ilmiöt, kuten tilanteet, joissa maahanmuuttajaperheiden lapset toimivat tulkkeina perheelleen ja tovereilleen, ja ylipäätään tilanteet, joissa joku toimii tulkkina vailla alan koulutusta eikä saa palkkaa palveluksistaan. Näin on esimerkiksi silloin, kun lääkärin vastaanotolla potilaan seurana oleva perheenjäsen tai vaikkapa sairaanhoitaja tulkkaa tapaamisen lääkärin ja potilaan välillä (Meyer, Pawlack \& Ortrun 2010). Spontaani kielenvälittäjä ei todennäköisesti toimi samalla tavalla kuin ammattitulkki toimisi. Yhtäältä tästä seuraa haasteita tulkkauksen laadun ja tulkattavien oikeusturvan näkökulmasta. Toisaalta spontaanien tulkkien ja kääntäjien tarjoama apu on merkittävää ja monessa tapauksessa suorastaan välttämätöntä. Ei-ammattimainen kielenvälitys on siis olemassa oleva ilmiö, jota on tarve ymmärtää paremmin.

Kääntämisen ja tulkkauksen tieteellinen tutkimus on keskittynyt pääasiassa ammattitoimintaan ja institutionaalisiin tilanteisiin. Nähdäkseni on kuitenkin niin, että ei-ammattimaista tulkkaustoimintaa ei voida arvioida suoraan eikä ainoastaan ammatillisin kriteerein, koska lähtökohdat toimintaan ovat niin erilaiset. Sen sijaan olisi tutkittava ei-ammattimaista kielenvälitystä sen omista lähtökohdista erilaisissa monikielisissä vuorovaikutustilanteissa. Näin voidaan ymmärtää paremmin kielenvälitystoiminnan itseohjautuvuutta ja vuorovaikutuksellista jäsentymistä. Saatua tietoa voidaan suhteuttaa myös sellaisen vuorovaikutuksen tarkasteluun, jossa maallikot joutuvat tulkkaamaan asiointitilanteiden institutionaalisissa raameissa. Tänään tarkastettava tutkimukseni arkikeskustelujen suullisesta kääntämisestä on yksi askel tämänkaltaisen tiedon kartuttamisessa.

Olen tarkastellut tilanteita, joissa kahdella tai useammalla läsnäolijalla ei ole sujuvaa yhteistä kieltä. He puhuvat joko suomea tai brasilianportugalia. Heidän lisäkseen paikalla on kuitenkin osallistujia, jotka puhuvat sekä suomea että portugalia. Keskustelun kuluessa nämä kahden kielen taitajat asettuvat kielellisiksi välittäjiksi muiden välille ja toisinaan kääntävät myös omaa puhettaan. He tekevät meneillään olevaa toimintaa ymmärrettäväksi erikielisille osallistujille ja siten voivat myös auttaa näitä ottamaan aktiivisesti osaa keskusteluun. Tarkemmin sanottuna kielenvälittäjät toistavat, kierrättävät tai kuvailevat aiempaa keskustelua eri kielellä sellaiselle läsnäolijalle, joka ei ole sitä mahdollisesti ymmärtänyt. Tällaista aiemman puheen esittämistä eri kielellä voidaan kutsua ei-ammattimaiseksi suulliseksi kääntämiseksi tai kielenvälitykseksi.

Mitä ja millaista ei-ammattimainen kääntäminen sitten käytännössä on? Aihetta kuvataan osuvasti Sofia Coppolan elokuvassa Lost in Translation, jonka myötä siirrymme hieman erilaiseen kontekstiin. Tarkastelemme seuraavaksi elokuvan kohtausta, jossa Bill Murrayn esittämä hahmo, näyttelijä nimeltä Bob Harris, on kuvaamassa mainosta Japanissa. Kuvausten ohjaaja antaa Bobille ohjeita japaniksi, ja avustajana toimiva nainen välittää ohjeet Bobille englanniksi. 
Alussa ohjaaja selittää pitkästi japaniksi, mitä Bobin tulisi tehdä kameran edessä. Avustajana toimiva nainen kääntää tuon ohjeen Bobille kuitenkin vain lyhyenä kehotuksena kääntää kasvot kohti kameraa. Hän sanoo:

(2) he wants you to turn (.) look in camera (...) okay 'hän haluaa että käännyt (.) katsomaan kameraan (...) okei'

Tässä vaiheessa Bob jo ihmettelee, tuliko koko ohjeistus toistettua. Kun Bob sitten tiedustelee, kummasta suunnasta hänen pitäisi katsoa kameraan, avustaja kääntää kysymyksen japaniksi varsin monisanaisesti. Ohjaaja vastaa jälleen pitkällä selityksellä, jonka avustaja kuitenkin kääntää Bobille sanoen ainoastaan:

(3) right side (.) and (.) with intensity (.) okay 'oikea puoli (.) ja (.) intensiivisesti (.) okei'

Bob on silminnähden hämmentynyt tilanteesta ja lausuu ilmi epäilyksensä siitä, että ohjaaja lienee sanonut muutakin:

(4) is that everything? I mean it seemed like he said quite a bit more than that 'siinäkö kaikki? minusta hän näytti sanovan aika paljon enemmän'

Fiktiivisen kohtauksen avulla voidaan nostaa esiin joitakin ei-ammattimaisen kielenvälityksen keskeisiä piirteitä. Ensiksi voimme panna merkille, että alkuperäisten puheenvuorojen ja niiden käännösten pituudet eivät vastaa toisiaan. Nainen kääntää japaninkieliset ohjeet englanniksi parilla sanalla, ja englanninkieliset kysymykset hän taas selittää japaniksi paljon alkuperäistä vuoroa monisanaisemmin. Ero vuorojen pituudessa on havaittavissa Bobille yhtä lailla kuin japania osaamattomalle katsojalle ja tekee heille näkyväksi sen, että alkuperäisen puheen ja käännöksen sisältö tai rakenne eivät voi vastata toisiaan. Kohtauksessa Bob suhtautuu siihen ongelmana.

Tässä tulee esiin ero elokuvan ja oikean elämän tilanteiden välillä. Oman aineistoni saati muun tutkimuskirjallisuuden perusteella ei ole kovin yleistä, että käännöksen vastaanottaja esittää epäilyksensä käännöksen vastaavuudesta ääneen. Sen sijaan osallistujien keskinäinen ymmärrys ja myös mahdolliset ongelmat, joita elokuvakohtaus osuvasti kuvaa, neuvotellaan ikään kuin rivien välissä. Neuvottelu tapahtuu sen kautta, miten osallistujat luovivat tilanteessa eteenpäin ja vastaavat toistensa toimintaan. Tämä pätee yleisestikin keskustelun rakentumiseen. Jokainen keskustelun vuoro osoittaa puhujansa tulkintaa meneillään olevasta sosiaalisesta toiminnasta (Sacks 1995; Sacks, Schegloff \& Jefferson 1974).

Elokuva vastaa aineistoni esimerkkejä siten, että tavallisesti käännösvuoro eroaa monin tavoin alkuperäisestä vuorosta. Onko käännös siis vain alkuperäisen viestin vaillinainen, epätäydellinen versio? Voidaan myös kysyä, onko avustajan tapa välittää vain pari keskeistä sanaa ohjeeksi Bobille jollakin tavalla epäonnistunutta kääntämistä. Alkuperäinen ohje ei välity näyttelijälle täsmällisesti saati kaikessa laajuudessaan, mikä aiheuttaa hänessä hämmennystä. Samalla käännös kuitenkin tarjoaa näyttelijälle tie- 
toa, jonka perusteella hän pystyy tulkitsemaan tilannetta ja toimimaan siinä siten, että mainos saadaan kuvattua. Ehkä käännetyt ohjeet ovat lopulta riittävät tilanteen päämääriin nähden. Vaikka paljon jää toistamatta, avustajan vuoro "right side and with intensity" kelpaa vastaukseksi Bobin tiedusteluun siitä, kummasta suunnasta hänen pitäisi kääntyä kohti kameraa.

Tässä vaiheessa voin myös paljastaa, että japanilainen ohjaaja on itse asiassa ilmaissut hänelle olevan se ja sama, mistä suunnasta Bob kääntyy kohti kameraa, kunhan he pääsevät nopeasti kuvaamaan.

(5) Ohjaaja (japaniksi)2: 'kumpi puoli tahansa käy, muuten ei saada edes mitään näytettävää. Ei meillä ole aikaa, nopeasti! Lisää intensiteettiä (...) katso kameraan, katseesi kohti kameraa, ja sulavasti, intohimoisesti...

Avustaja: right side (.) and (.) with intensity (.) okay 'oikea puoli (.) ja (.) intensiivisesti (.) okei'

Välittäessään ohjeen Bobille avustaja siis valitsee itsenäisesti oikean puolen, ja Bob saa vastauksen tiedusteluunsa. Näin kääntäjä sovittaa vuoronsa vastaanottajan tarpeisiin. Vastaanottajan huomioiminen voikin motivoida toistetun asian muokkaamista monin tavoin. Olennaista on myös se, että vaikka erikielisellä osallistujalla ei olisi pääsyä keskustelun kielelliseen sisältöön, hän voi nähdä ja kuulla, kuka puhuu, tulkita muiden osallistujien äänensävyjä ja ilmeitä, puheen rytmiä ja jaksottumista sekä fyysistä toimintaa, johon hän voi myös itse osallistua. Elokuvan kohtauksessa Bob kiinnittää aktiivisesti huomionsa siihen, mitä japanilainen ohjaaja tekee. Toisin sanoen hän asettuu japaninkielisen puheen vastaanottajaksi siitä huolimatta, ettei ymmärrä kieltä. Käännöspuhe luo yhdessä kaiken muun saatavilla olevan informaation kanssa jonkinlaista kuvaa tuosta ympäröivästä todellisuudesta, samalla sitä muokaten.

Kielenvälityksen tarkastelussa on huomioitava välittäjän ammattimaisuuden lisäksi se, millaisessa tilanteessa kääntäminen tapahtuu. Omassa työssäni tarkastelen arkisia tilanteita kotona sekä muualla perheen, ystävien ja tuttavien kesken. Keskustelu virtaa vapaasti, osallistujia on useita, eikä tilanteeseen liity sellaista institutionaalista epäsymmetriaa ja valtasuhteita kuin tähän asti esittämissäni tapauksissa. Arkisen kielenvälitystoiminnan tutkimus voikin nostaa esiin ilmiöitä, joita ei institutionaalisessa vuorovaikutuksessa tai ammattitoiminnassa välttämättä esiinny lainkaan. Voidaan kuitenkin myös olettaa, että osin arjen käytänteet kantautuvat niihin tilanteisiin, joissa kaksikieliset ovat varsinaisessa tulkin roolissa.

Millaista kääntäminen omassa aineistossani sitten on? Kääntämisen päämäärät ja seuraukset ovat arkisessa keskustelussa usein erilaisia kuin ammattikontekstissa. Esimerkiksi pyrkimys toistaa lähdeteksti tai lausuma mahdollisimman hyvin alkuperäistä vastaavana on yksi klassisia teemoja kääntämisen ja tulkkauksen tutkimuksessa (ks. Pym 2010). Tämä pyrkimys ei kuitenkaan välttämättä sisälly arkikääntämiseen lainkaan samalla tavalla tai samassa määrin kuin ammattikontekstissa, eikä arki-

2. Käännetty japanista yhteistyössä Misao Okadan kanssa. 
keskusteluissa välttämättä voida määrittää yhtä alkuperäistä lausumaa, jota kääntämällä välitettäisiin.

Sen sijaan arkikeskustelun kielenvälittäjät tekevät meneillään olevaa vuorovaikutusta ymmärrettäväksi erikieliselle osallistujalle monin eri tavoin. He nostavat etualalle sellaisia edeltävän keskustelun sisältöjä ja näkökulmia, jotka ovat juuri sillä hetkellä ja senhetkisen toiminnan tarpeisiin nähden olennaisia. Aina ei edes ole varsinaisesti kyse siitä, että puhuja auttaisi muita osallistumaan keskusteluun, vaan hän voi kääntämällä edistää myös omia tarkoitusperiään, vaikkapa vahvistaa aiemmin esittämäänsä mielipidettä. Kielenvälittäjät voivat kääntäessään yhtä hyvin lisätä yksityiskohtia ja taustatietoa kuin tiivistää aiemman parilla sanalla tai jopa yleistää yksittäisen puhetapahtuman yleiseksi asiantilaksi. Näin käännöspuheen ja sen välittämän aiemman puheen ja toiminnan välille voi syntyä hyvinkin erilaisia sisällöllisiä ja toiminnallisia suhteita.

Väitöstutkimuksessani kuvaan yksityiskohtaisesti sitä, miten puhujien tavat välittää meneillään olevaa keskustelua eri kielellä ovat sidoksissa tilanteen yleiseen vuorovaikutukselliseen jäsentymiseen. Kuten otsikosta käy ilmi, nimitän näitä puhujien keinoja esittää aiempaa puhetta keskustelun translatorisiksi käytänteiksi. Käytänteillä tarkoitan, että käännösvuoro tuotetaan jossakin tunnistettavassa muotissa, jolle on löydettävissä tietynlaisia funktionaalisia ominaispiirteitä.

Työni punaisena lankana on käännösvuorojen ja niiden kielellisten rakenteiden analyysi erityisesti siitä näkökulmasta, miten puhujat sekä sopeuttavat käännöspuhetta senhetkiseen tilanteeseen että vaikuttavat vuorovaikutuksen etenemiseen. Selvitän muun muassa sitä, miksi puhujat ryhtyvät kääntämään keskustelua juuri tietyllä hetkellä. Paikallisesti syntyvä tarve kääntämiselle on monen asian summa. Siihen vaikuttavat muun muassa osallistujien tiedolliset alueet, keskustelun affektiset sävyt ja erityisesti se, miten eri kielen puhuja osoittaa kehollisesti asemaansa vuorovaikutuksen osallistujana. Usein pelkkä vilkaisu puhujaan päin sopivalla hetkellä riittää kutsumaan kielenvälitystä.

Erilaiset kääntämisen tavat liittävät käännösvuoron keskustelukontekstiinsa eri tavoin. Palataan vielä hetkeksi elokuvakohtauksen englanninkielisiin käännösvuoroihin. Seuraavat kaksi lausumaa havainnollistavat jaottelua, jonka olen tehnyt tutkimuksessani käännösvuorojen päätyyppien välille.

(6) i) he wants you to turn (.) look in camera (...) okay 'hän haluaa että käännyt (.) katsomaan kameraan (...) okei'

ii) right side (.) and (.) with intensity (.) okay 'oikea puoli (.) ja (.) intensiivisesti (.) okei'

Ensimmäisessä englanninkielisessä vuorossaan nainen viittaa edelliseen puhujaan persoonapronominilla he 'hän' ja lisäksi kuvaa sanallisesti tämän äskeistä toimintaa verbillä want 'haluta'. Se, mitä ohjaaja haluaa, ilmaistaan vuoron loppuosassa. Käännösvuoro siis sisältää kehystävän rakenteen, jossa viitataan aiempaan puhujaan ja tämän toimintaan, minkä jatkoksi tuotetaan varsinainen käännettävä sisältö. Jälkimmäisessä käännösvuorossa puhuja menee suoraan asiaan. Vuoro koostuu pelkistä substantii- 
veista, joita yhdistää konjunktio and 'ja' sekä prepositio with. Siis suomeksi 'oikea puoli (.) ja (.) intensiivisesti'.

Työssäni kutsun näitä kahta kääntämisen tapaa kehystetyiksi ja kehystämättömiksi käännösvuoroiksi. Kehystettyjen vuorojen alussa esiintyy elementtejä, jotka osoittavat vastaanottajalle, että sanottu asia on lainattu edeltävästä puheesta. Kehystämättömien vuorojen kohdalla taas voidaan kysyä, miten ne tulevat vastaanottajalle ymmärrettäväksi käännöksinä, kun niissä ei mitenkään tuoda ilmi suhdetta aiempaan puhujaan. Ja edelleen, jos jotkut vuorot ovat tällaisenaan riittäviä aiemman puheen välittämiseen, miksi kehystävät elementit ovat tarpeellisia toisissa käännösvuoroissa?

Työssäni osoitan, että meneillään oleva toiminta ja keskustelun rakenteet tarjoavat paikkoja tuottaa käännösvuoroja tietyillä tavoilla. Puhujien käännösvuorojen alussa käyttämät kielelliset rakenteet luovat osaltaan kytköksiä aiempaan keskusteluun ja ennakoivat tulevaa vuoroa. Eri tavoin kääntämällä välittäjä suhteuttaa vuoronsa paikallisesti syntyviin vuorovaikutuksen tarpeisiin ja tekee kääntämisestä ja sen myötä etenevästä toiminnasta tilanteisesti motivoitua ja ymmärrettävää.

Tutkimukseni käsittelee yksityiskohtaisia kielenpiirteitä ja vuorovaikutuksen hienovaraista jäsentymistä, mutta se on myös tutkimus erilaisuuden kohtaamisesta, ruohonjuuritason integraatiosta toiseen kulttuuriseen ympäristöön ja siitä, miten keskustelun osallistujat ymmärtävät sen osallistujan näkökulmaa, jolla on kielivalinnan vuoksi rajalliset mahdollisuudet osallistua. Tuloksena ei ole vain harmoniaa ja yhteisymmärrystä vaan myös ulkopuolisuutta ja väärinymmärryksiä. Kirkkaimpana esiin nousevat kuitenkin keskustelun osallistujien kyky tasapainoilla epäsymmetrisessä tilanteessa ja heidän käyttämiensä vuorovaikutuksellisten keinojen vivahteikkuus.

\section{Lähteet}

Angermeyer, Phillip 2015: Speak English or what? Codeswitching and interpreter use in New York City courts. New York: Oxford University Press.

Antonini, Rachele - Cirillo, Letizia - Rossato, Linda - Torresi, Ira 2017: Nonprofessional interpreting and translation. Amsterdam: John Benjamins.

Asioimistulkin ammattisäännöstö 2013. http://www.tulkit.net/ammatti/asioimistulkin-ammattisaannosto (18.10.2016).

BOLDEN, GALINA 2000: Towards understanding practices of medical interpreting. Interpreters' involvement in history taking. - Discourse Studies 4 s. 387-419. https://doi.org/10.1177/ 1461445600002004001.

HARRIS, BRIAN 2012: An annotated chronological bibliography of natural translation studies with native translation and language brokering, 1913-2012. http://www.academia. edu/5855596/Bibliography_of_natural_translation (28.4.2014).

Kolehmainen, Leena - Koskinen, Kaisa - Riionheimo, Helka 2015: Arjen näkymätön kääntäminen. Translatorisen toiminnan jatkumot. - Virittäjä 119 s. 372-40o.

Leinonen, Nina 2017: Maahanmuuttovirasto: Surkea tulkkaus on syy valittaa. - Iltalehti 18.1.2017.

Maahanmuuttovirasto 2017: Oikeus tulkkiin ja oikeudelliseen avustajaan. http://www.migri.fi/ turvapaikka_suomesta/turvapaikan_hakeminen/turvapaikkapuhuttelu (23.5.2017). 
Meyer, Bernd - Pawlack, Birte - Ortrun, Kirstin 2010: Family interpreters in hospitals. Good reasons for bad practice? - mediAzioni 10 s. 297-324.

Pym, Anthony 2010: Exploring translation theories. London: Routledge.

Reinboth, Susanna 2017a: Suomeen paennut nigerialaisnainen kertoo poikajoukon polttaneen hänen tyttöystävänsä hengiltä - veivätkö tulkkausongelmat turvapaikan? - Helsingin Sanomat 27.5.2017.

— 2017b: Migri: Yksittäisten turvapaikkapuhuttelujen tulkkauksissa on havaittu ongelmia - "Tulkin sanavaraston pitää olla hirveän hyvä". - Helsingin Sanomat 27.5.2017.

SACKS, HARVEY 1995 [1992]: Lectures on conversation, Vol. I \& II (toim. Gail Jefferson). Oxford: Basil Blackwell. https://doi.org/ 10.1002/9781444328301.

Sacks, Harvey - Schegloff, Emanuel A. - Jefferson, Gail 1974: A simplest systematics for the organization of turn-taking for conversation. - Language 50 s. 696-735. https://doi.org/ 10.2307/412243.

Suomen kääntäjien ja tulkkien liitto 2017: Migrin kanssa keskustelua muun muassa tulkkauksesta. https://www.sktl.fi/?x18668=1298424 (17.5.2017).

Ulkomaalaislaki 2004/301. http://www.finlex.fi/fi/laki/ajantasa/2004/20040301\#L1.

WADENSJÖ, CECILIA 1998: Interpreting as interaction. London: Longman.

Katariina Harjunpää: Translatory practices in everyday conversation. Bilingual mediating in Finnish-Brazilian Portuguese interaction. Helsinki: Unigrafia. Kirja on luettavissa osoitteessa http://urn.fi/URN:ISBN: 978-951-51-3227-7.

Kirjoittajan yhteystiedot:

etunimi.sukunimi@helsinki.fi 